\title{
特集小児脳神経外科疾患の課題と展望
}

潜在性二分脊椎

吉藤 和久 ${ }^{1)}$ ，大森 義範 ${ }^{1)}$ ，小柳 泉 ${ }^{2)}$ ，師田 信人 ${ }^{3)}$ ，三國 信啓 ${ }^{4}$

1）北海道立子ども総合医療・療育センター脳神経外科，2）北海道脳神経外科記念病院，3）東京都立小児総合医療センター脳 神経外科，4）札幌医科大学脳神経外科

\section{Spina Bifida Occulta}

Kazuhisa Yoshifuji, M.D. ${ }^{1)}$, Yoshinori Omori, M.D. ${ }^{1}$, Izumi Koyanagi, M.D. ${ }^{2)}$, Nobuhito Morota, M.D. ${ }^{3)}$, and Nobuhiro Mikuni, M.D. ${ }^{4)}$

1) Division of Neurosurgery, Hokkaido Medical Center for Child Health and Rehabilitation, 2) Hokkaido Neurosurgical Memorial Hospital, 3) Division of Neurosurgery, Tokyo Metropolitan Children's Medical Center, 4) Department of Neurosurgery, Sapporo Medical University

Spina bifida occulta (SBO) is a malformation of the spinal cord and its surrounding structures. It is caused by the failure of neurulation and is defined as a condition characterized by the absence of cerebrospinal fluid leakage without skin defects; therefore, it is also known as closed spinal dysraphism. Here we have reviewed the embryology-based pathogenesis, outlined clinical pictures of whole SBO including our clinical data, and mentioned individual disease states.

SBO comprises various pathological conditions related to the type of failure during notochord formation and primary and secondary neurulations. Neurological disorders are caused by spinal cord tethering, mass effect, and dysplasia of the nerve tissue. Comorbid cutaneous abnormalities and lower intestinal and urogenital anomalies are initial signs for the diagnosis of SBO. Surgery for tethered spinal cord and mass effect, except for dysplasia of the nerve tissue, possibly help in the improvement or stabilization of symptoms. Surgery is generally recommended in symptomatic SBO cases and in asymptomatic SBO cases in children; however, prophylactic surgery is controversial. Comprehensive care and postoperative follow ${ }^{-}$up are necessary over a prolonged period.

(Received February 16, 2018; accepted March 9, 2018)

Key words : spina bifida occulta, closed spinal dysraphism, embryology, primary neurulation, secondary neurulation

Jpn J Neurosurg（Tokyo）27 : 662-669, 2018

\section{はじめに}

潜在性二分脊椎（spina bifida occulta）は神経管形成時 の異常による先天奇形である。通常は閉鎖性（髄液漏の ない，皮膚欠損のない）二分脊椎を意味する。この他， 潜在性が顕在性と対で用いられると, 䯣液漏にかかわら
ず前者は形態的に瘤を形成しないもの, 後者は瘤を形成 するものを指す場合がある. 実地臨床上, 髄液漏の有無 が重要で，これにより症状，合併病変，治療方針が大き く異なることから，「潜在性＝閉鎖性」として用いること が多く, 本稿でもそのように扱う。

潜在性二分脊椎は，神経管発生障害の時期や種類によ

連絡先：吉藤和久, $=006-0041$ 札幌市手稲区金山 1 条 1-240-6 北海道立子ども総合医療・療育センター脳神経外科

Address reprint requests to: Kazuhisa Yoshifuji, M.D., Division of Neurosurgery, Hokkaido Medical Center for Child Health and Rehabilitaion, 1-1-240-6 Kanayama, Teine-ku, Sapporo-shi, Hokkaido 006-0041, Japan 


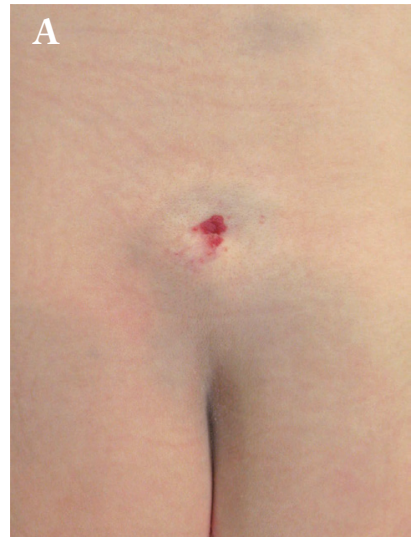

$100 \%(25 / 25)$

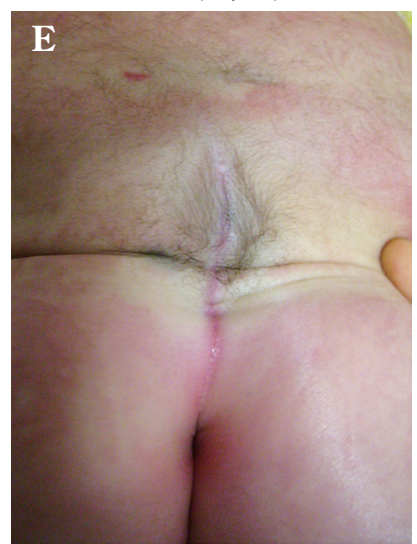

$67 \%(4 / 6)$

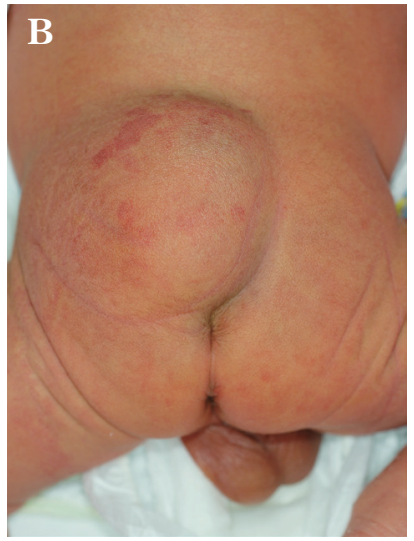

$98 \%(39 / 40)$

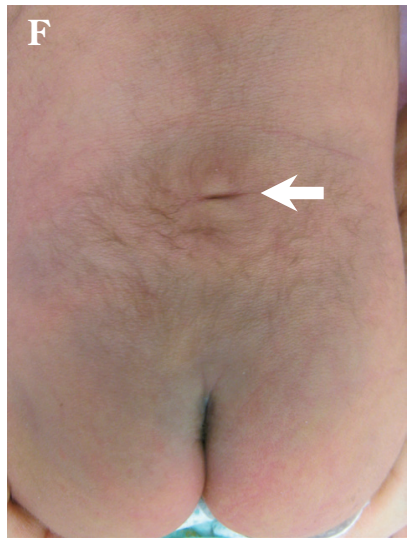

$62 \%(8 / 13)$

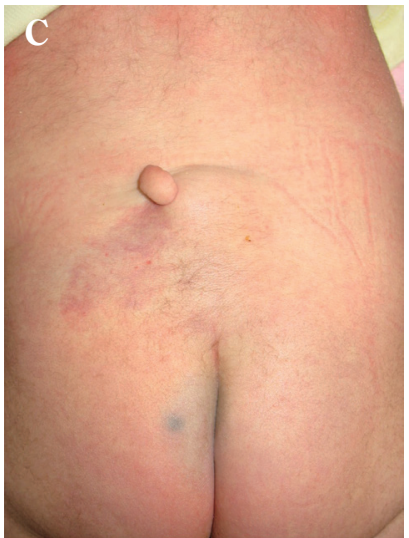

$80 \%(8 / 10)$

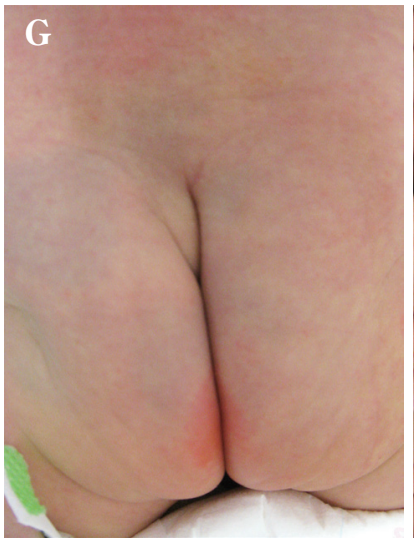

$30 \%(21 / 69)$

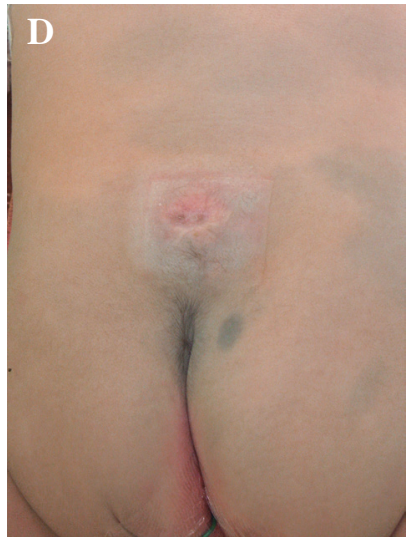

$77 \%(10 / 13)$

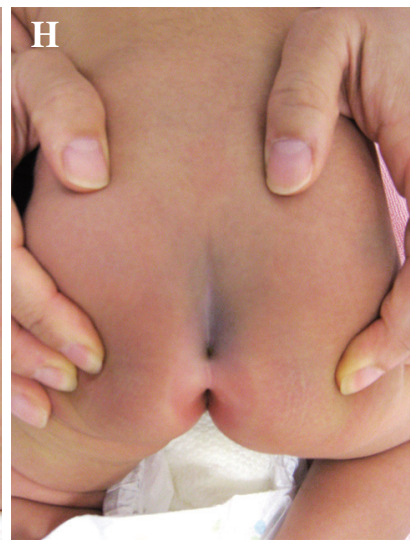

$1.2 \%(1 / 83)$

Fig. 1 Cutaneous lesions

Hemangioma (A), subcutaneous mass (B), skin tag (C), cigarette burn mark (D), abnormal hair (E), extragluteal cleft dimple (F, arrow), irregular gluteal cleft $(\mathbf{G})$, and coccygeal dimple $(\mathbf{H})$. Each number indicates the prevalence of spina bifida occulta as a therapeutic objective in our experience $(n=255)$.

まで幅広いが，開放性二分脊椎より一般に軽い，障害の 発生機序は神経組織の先天的形成不全, 脊䯣係留, 脊髄 圧迫，脊髄空洞，感染（先天性皮膚洞の場合），機械的損 傷（lipomyelomeningocele など神経組織が脊椎管外の皮 下まで出ている場合)である，神経組織形成不全以外は， 外科的治療が有効とされる ${ }^{19)}$.

\section{2 皮膚病変 (Fig. 1)}

背部皮膚病変がしばしば診断の契機となり, tell-tale sign（告げロサイン）や stigmata（烙印）と呼ばれる. 皮膚と神経は同じく外胚葉から発生するので, 皮虐正中 部に異常があれば神経組織の異常を疑う必要がある。皮 膚病変と神経病変は先天性皮膚洞のようにつながってい ることもあるが, 必ずしも解剖学的に連続している病態 ばかりではない. 評価の際は皮膚病変が脊椎管内に達し ていなくても, 脊髄まで撮像し確認する必要がある. 確 実な評価にはMRIが必須とされる. 各皮膚病変が手術適
応のある神経病変を合併する率は, 自験例の連続 255 例 〔2008〜2017 年, 生後 0 力月〜 13 歳 (中央值 4 力月) 〕に よれば，血管腫：100\%（25/25），皮下腫瘤：98\%（39/ $40)$, 人尾: $80 \%(8 / 10)$, cigarette burn mark: 77\%（10/ 13), 異常発毛: $67 \%(4 / 6)$, 慰裂不整: $30 \%(21 / 69)$, 慰裂上端より頭側に存在する皮膚陥凹：62\%（8/13）で あった（Fig. 1)。過去の報告でも皮下腫瘤, 人尾, cigarette burn mark, 異常発毛を合わせると $55 \%$ に神経病変 を伴うとされる ${ }^{13)}$.これらの皮膚病変を認める症例は精 査が勧められる。一方, 慰裂内下部に存在し底が尾骨へ 向かう皮膚陥凹 (Fig. 1H) は小児人口の $2 \sim 4 \%$ に存在し 頻繁に遭遇するが, 治療を要する潜在性二分脊椎の合併 はまれである $(0 \sim 7 \%)^{5) 6) 13)}$. 自験例では $1.2 \%(1 / 83)$ であった，精査はすべきという意見と必ずしも必要ない という意見がある ${ }^{523)}$. 


\section{3 脊椎の異常}

椎弓の形成不全や後方への扉状開放は, 二分脊椎と呼 ばれる所以である。皮下から硬膜内まで連続する病変 (脊髄脂肪腫, 先天性皮膚洞など) ではその通路となり, 筋層, 硬膜も欠損する. 椎体異常や脊椎管内骨性中隔は, 春索形成異常に伴いやすい. 仙骨奇形は二次神経管形成 異常に多い.

小児では単純 X 線写真や CT を撮影すると, 健常児で も椎弓正中部が欠損していることがある。成長過程とし ての未骨化軟骨結合 (synchondrosis)の画像所見であり， 病的二分脊椎とは異なる。新生児では全脊椎レベルで認 められ, 腰仙部が最も遅く約 15 歳まで認められる。 た，不完全な椎弓形成として残ることも多く，人口の 5 30\%にみられ，S1，L5 高位に多い ${ }^{11)}$ 。病的二分脊椎 との鑑別には椎弓の変形, 左右差, 異所性骨化, 椎弓根 間の拡大に注目する ${ }^{25)}$.

\section{4 合併病変}

下部消化管奇形, 泌尿 - 生殖器奇形, 仙骨奇形, 尾部 退行症候群 (caudal regression syndrome) (VATER 連合, VACTERL 連合, OEIS 症候群など) が, 二次神経管形成 異常に合併しやすい。二次神経管が排泄腔 (cloaca) と解 剖学的に近接し発生上関連しているためである ${ }^{21)}$ 。これ らの合併率は, 自験例 96 例〔2008 2017 年, 生後 0 力 月〜14 歳（中央值 7 力月）」によれば, 二次神経管由来の 疾患 (S2 以下の脊髄と終系の疾患) の $36 \%(27 / 72)$, 一 次神経管由来の疾患 $(\mathrm{S} 1$ 以上頭側の疾患) の $4 \%(1 / 24)$ であった $(\mathrm{p}<0.01$ : Fisher's exact test).二次神経管由来 の疾患の $39 \%$ に合併するという報告もあり ${ }^{12)}$ ，これらを 伴う児には MRI 検査が勧められる.

開放性二分脊椎（いわゆる脊髄髄膜瘤）と異なり，髄 液漏が原因で生じるキアリ奇形や水頭症は伴わない.

\section{治 療}

手術適応・方法については各疾患の項で述べたい. 手 術後のフォローアップも大切で, 長期にわたり, 少なく とも成長が終了するまで, 再係留による症状再発や脊髄 空洞出現に配慮し経過観察する. 脳神経外科以外に, 泌 尿器科による排尿機能評価と管理, 整形外科による装具 治療や矯正手術，リハビリテーション科・小児科による 機能発達の評価や訓練など, 包括的医療が必要である.

\section{潜在性二分脊椎の各疾患}

\section{1 分離脊髄奇形 (split cord malformation: SCM)}

(Fig. 2A, B)

脊索形成時の異常による。他の二分脊椎にしばしば合 併し, SCM の 26〜80\%は開放性二分脊椎に伴って診断 される，2つの脊髄がそれそれ硬膜囊をもち，骨性ある いは線維軟骨性中隔が存在する Type I (割髄症, diastematomyelia）（Fig. 2A）と，2つの脊髄が 1 つの硬膜囊内 で線維性中隔により境される Type II（重複脊髄, diplomyelia）（Fig. 2B）がある。神経症状は, 脊髄係留と神経 組織形成不全による。症候性例は手術適応であり, 無症 候性例の予防手術には議論がある。手術は中隔切除によ る脊髄係留解除である ${ }^{14)}$.

\section{2 先天性皮膚洞（Fig. 2C)}

一次神経管閉鎖時の異常で, 皮膚外胚葉と神経板の分 離不全 (incomplete disjunction) による.上皮をもつ管腔 構造で, 背部の皮膚陥凹から連続し, 硬膜外まで（10～ $36 \%)$ ，硬膜内まで（53～60\%），あるいは脊䯣まで達す る $(13 \%)$. 腰仙部 $(88 \%)$ が多く, 胸椎 $(10 \%)$ や䅡椎 $(<1 \%)$ は少ない. 類皮腫 $(43 \sim 83 \%)$, 類上皮種 $(13 \%)$, 奇形腫（4\%）を合併する. 䯣膜炎は 23〜 59\%, 局所感 染を含む何らかの感染が 31〜 $61 \%$ にられる. 神経症状 は感染, 脊䯣係留, 圧迫（類皮腫, 膿瘍などによる), 神 経組織形成不全が原因となる。髄膜炎による障害や, 硬 膜下膿瘍による急速な対麻痺は予後に影響するため, 早 期予防手術が针められる。手術は皮膚洞と類皮腫の全摘 出である。管腔内の感染巣を考慮し, 管腔を開放せず一 塊として摘出する工夫が必要である。しかし, 春髄髄内 へ達し癒着している場合は難しい18)21).

3 Limited dorsal myeloschisis (LDM) (Fig. 2D) 一次神経管閉鎖時の分離不全（incomplete disjunction） による、特徵的な皮膚病変 (cigarette burning)（Fig. 1D） から脊髄背面へ, 上皮を含まない fibroneural tract が連続 する. Dorsal tethering band や meningocele manqué の概 念と重なるところが多い. 頝胸椎の non-terminal myelocystocele は, LDM の saccular type と考えられる. 感染 は起こさない, 神経症状は脊髄係留, 神経組織形成不全 による。手術は索状物全摘出による脊髄係留解除術で, 予防的にも行われる ${ }^{15)}$.

\section{4 脊髄脂肪腫 (Fig. 3)}

発生中の神経管に中胚葉組織が迷入して起こる奇形 

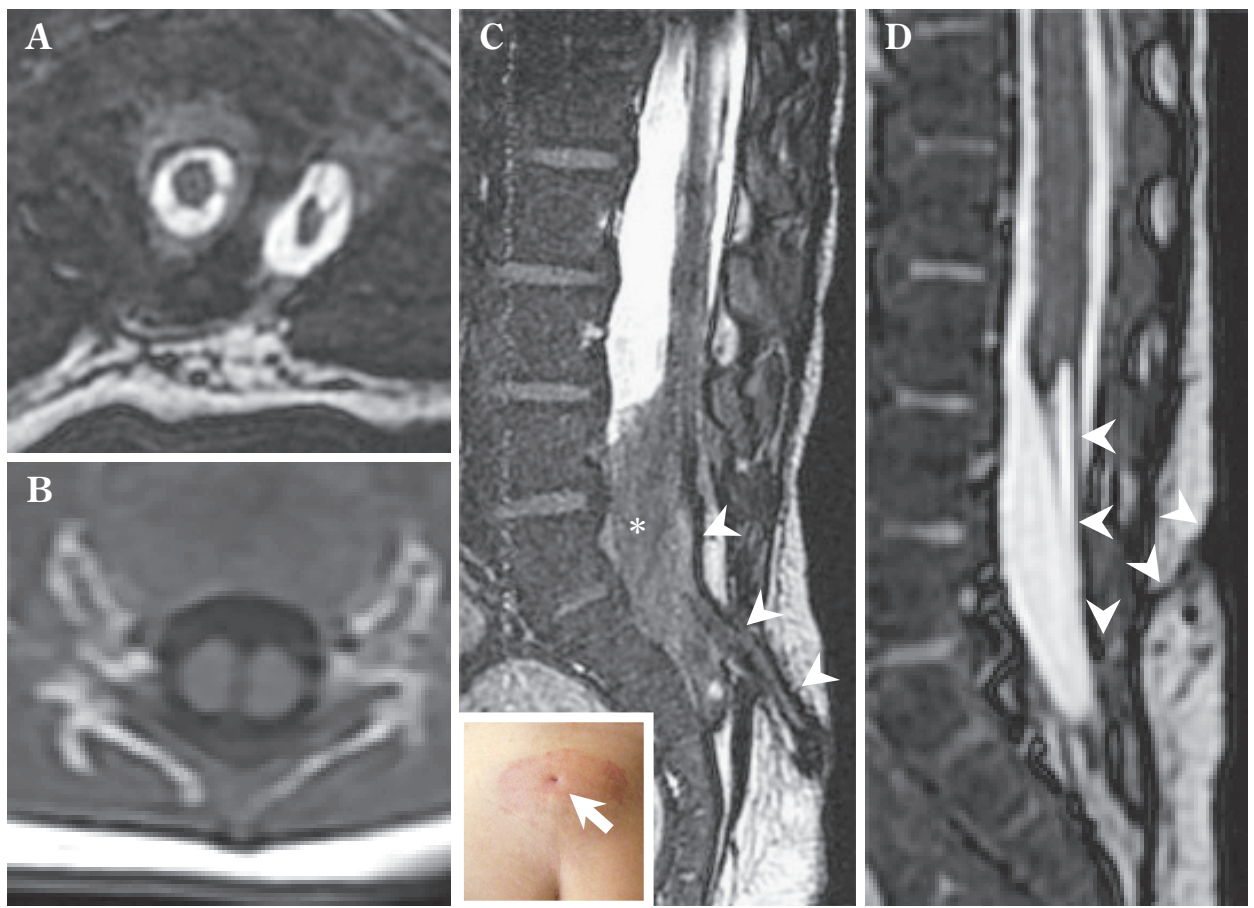

Fig. 2 Split cord malformation Type I (diastematomyelia) (A), Type II (diplomyelia) (B). Congenital dermal sinus (C) has a hollow structure lined with epithelia from the skin to the spinal cord (arrowheads). Infected dermoid (asterisk). Ostium of the dermal sinus indicating infection with surrounding skin inflammation (arrow). Limited dorsal myeloschisis (D) comprises the fibroneural tract without epithelium between the skin and the spinal cord (arrowheads).

(異所性脂肪組織) である。増殖はしないが, 肥満やるい 瘦によって皮下脂肪と同様に増減する。神経症状の原因 は脊䯣係留, 圧迫, 神経組織形成不全である。分類は MRI 所見に基づき 5 型に分け Arai $ら^{1)}$ の分類（2001 年） を用いることが多い: (1)dorsal type, (2)transitional type, (3)lipomyelomeningocele, (4)caudal type, (5)filar type (Fig. 3 にそれぞれの詳細を記す)。発生上(1)は一次神経管閉鎖 障害に由来, (4) と (5)は二次神経管形成異常, (2) と (3)は両 方が関与する (Table 1). 近年, MRI 上の形態に発生学 的視点を加味した Morota らの分類（2017 年）により, 臨床像の理解, 切除方法がより明瞭となった ${ }^{12}$.

1. 円錐部脂肪腫（1)～(4)）の手術適応（5)filar type については5終系病変を参照)

症候性例は手術が勧められる。無症候例では経過観察 を勧める意見もあるが, 1990 年代後半以降は手術のほう が予後良好という報告が多い. Progression-free survival （PFS）が手術例 87\%（経過観察期間 6.2 10.4 年, $\mathrm{n}=$ $103)^{8) 22)}$, 非手術例 $60 \sim 71 \%(9 \sim 10 \text { 年, } \mathrm{n}=133)^{7) 22)^{24)}}$ と報告されている，近年, 全摘出することにより PFSが 88.1\%（経過観察期間 20 年, $\mathrm{n}=315$ ）とも報告されてい るが, (2)transitional type, (3)lipomyelomeningocele では全
摘出の難しいものが多く, 再係留率が高くなる ${ }^{16)}$. 非手 術群では, 長期観察中に緩徐に出現する神経障害を早期 診断することが容易でないこと, 症候化後の手術で改善 するとは限らないことが問題となる。

\section{2. 円錐部脂肪腫の手術手技}

はじめに脂肪腫と神経組織の関係が単純な dorsal type について述べる。下肢誘発筋電図 (EMG) を術中神経 マッピングのために, 球海綿体反射 $(\mathrm{BCR})$ を膀胱直腸 機能モニタリングのために準備する. 脂肪腫の頭尾側で 正常くも膜下腔が確保できるよう, 椎弓切開範囲を決定 する. 皮膚切開し, 正常筋膜をたどり, 筋膜を貫通する 脂肪腫の ‘茎”を確保する。頭尾側で形成的椎弓切開を 行う。頭側の正常硬膜を切開し, 脊髄, 脂肪腫, 神経根 の関係を確認しながら尾側へ向かい，左右の硬膜を脂肪 腫から遊離する。同じことを尾側から追加することもあ る. 続いて短い終糸を切断すると, 脊髄・脂肪腫複合体 が神経根のみで硬膜とつながる状態となり, 係留解除が 完了する. 脂肪腫は可及的切除（部分切除）を基本とす る。近年, 発生学的に春髄との関係が単純な dorsal type などの場合に全摘出を勧める意見があり, 病変に応じ適 応を使い分けることで成績がよいとされる ${ }^{12)}$ ，再係留予 

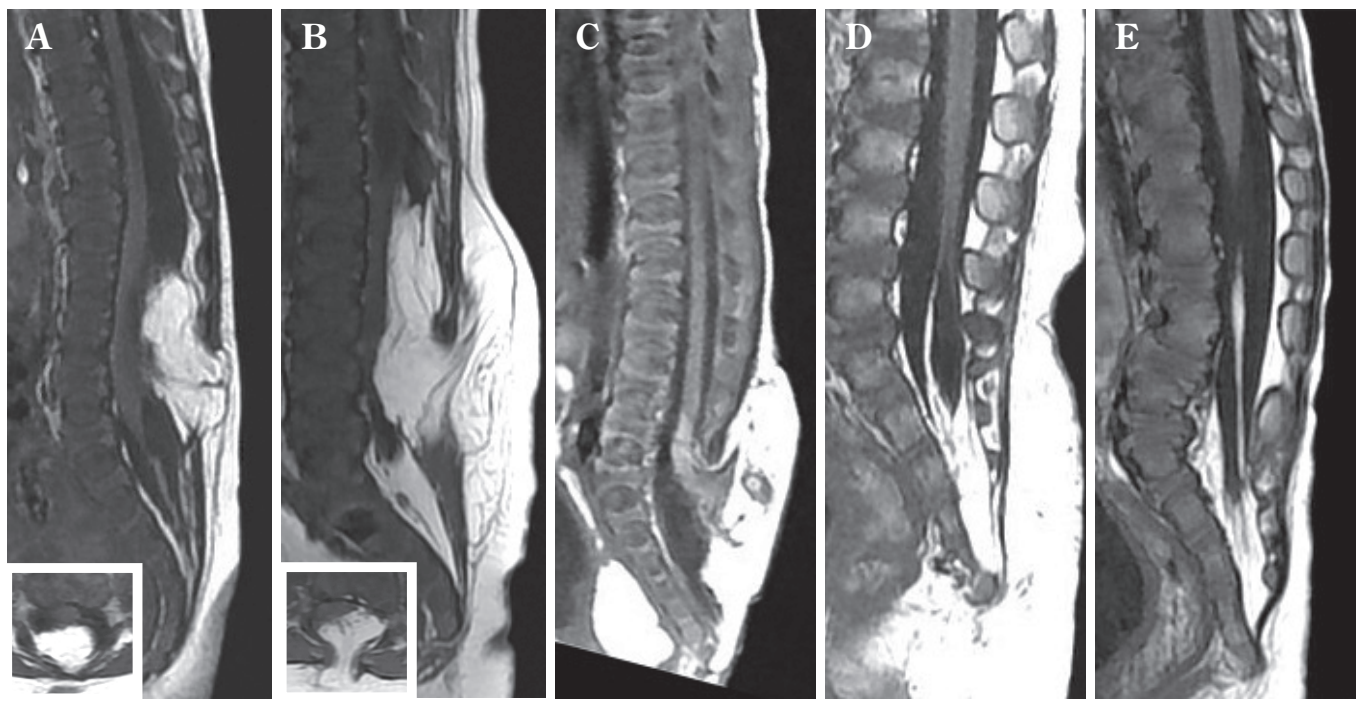

Fig. 3 Classification of spinal lipoma (Arai, et al 2001)

A : Dorsal type. The lipoma-cord interface is entirely on the dorsal surface of the spinal cord. Spinal conus is intact.

B : Transitional type. Lateral and ventral extension encasing the nerve roots.

C : Lipomyelomeningocele. The spinal cord and the subarachnoid space protrude out of the spinal canal. The nerve roots are occasionally encased.

D : Caudal type. Caudal attachment to the conus medullaris occasionally encasing the nerve roots. This case has an expanded central canal.

E : Filar type. Lipoma at the filum terminale.

防目的に，可能であれば春髄形成（軟膜縫合）を行う。 同じ目的で硬膜は余裕をもって形成すべきで，必要に応 じ筋膜で補堑する（小児ではできるだけ代用硬膜は使用 しない)，術後 cord/sac ratio（硬膜囊径に対する脊髄・ 脂肪腫複合体の割合）が小さいほど長期成績がよい ${ }^{16)}$. 以上が基本的手技である. Transitional type では脂肪腫に 巻き込まれた神経根を残しながら係留解除しなければな らず，脊髄と脂肪腫の境界も入り組んで不明瞭である. Lipomyelomeningocele では, 脱出脊髄を虽離し硬膜内一 完納する必要がある。神経根がしばしば脂肪腫に巻き込 まれ，脊髄と脂肪腫の境界も複雑である。C Caudal type で は脊髄の尾側で切除する。神経根を巻き込んでいる場合 は，その尾側で脂肪腫を切断し係留解除とする．硬膜囊 尾側端が先天的に形成されていないため, 脂肪腫を一部 利用し水密に再建する。

5 終糸病変一終糸脂肪腫 (Fig. 3E) と肥厚終糸 (Fig. 4A) -

二次神経管形成異常による。終系脂肪腫は終糸に限局 した脂肪腫で，任意に撮影した MRI 上 $0.24 \sim 4 \%$ に認め られる。ほとんどは無症候性で低位脊髄円錐を呈さず, 病的意義はない。肥厚終糸 (thickened filum)〔緊縛終糸 （tight filum terminale）ともいう了は径 $2 \mathrm{~mm}$ 以上の終糸 を指し，線維成分が主体で少量の脂肪組織を含む場合も ある。両者とも低位脊髄円錐を呈する場合，係留負荷に よる神経障害が危惧される。

症候性例は症状改善 (53\%) あるいは進行停止 (47\%) を目的に手術適応がある ${ }^{17)}$ 。低位脊髄円錐を認めるもの の無症候である例への予防手術は意見が分かれるが3), 症候化時の早期診断が容易でないこと, 症候化後の手術 で改善するとは限らないこと, 手術リスクが低いことか ら手術を選択する傾向にある ${ }^{17) 1921)}$. 正常円錐高位で あっても，脊髄症状（主に神経因性膀胱）を呈する場合 は手術が選択肢となる。このような病態は occult tethered cord syndrome と呼ばれる. 脊髄空洞が存在する場 合も手術が検討される。手術では 1 レベルの骨形成的椎 弓切開を行い, 終糸を切断する.

\section{6 終末部脊髄囊瘤 (Fig. 4B)}

二次神経管形成時の空洞（terminal balloon）が正常に 退縮せず発生する。脊髄下端の中心管が拡張し，春髄は ラッパ状に広がって, 䯣膜瘤を伴い脊椎管外へ脱出す る。神経症状は脊髄係留と神経組織形成不全による。総 排泄腔外反，仙骨奇形などを合併しやすい。症状の有無 

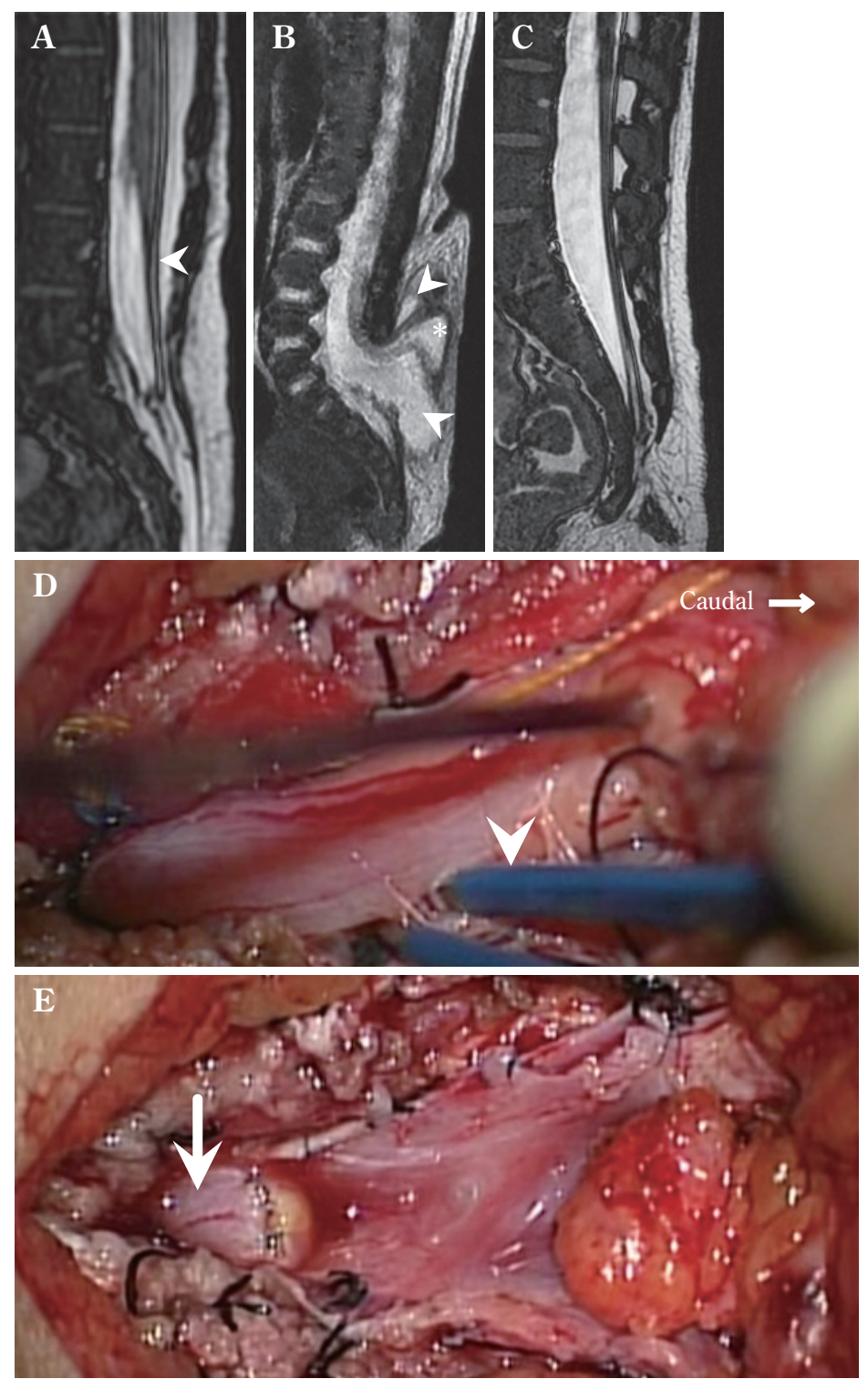

Fig. 4 Thickened filum (A, arrowhead) with a low set conus. Terminal myelocystocele (B) shows a dilated central canal of the spinal cord (asterisk) and the surrounding subarachnoid space (arrowheads). Retained medullary cord $(\mathbf{C}-\mathbf{E})$. The conus medullaris cannot be detected on MRI (C) or visually during surgery (D). The non-functioning region (medullary conus) is electrophysiologically determined ( $\mathbf{D}$, arrowhead), and resected from the true conus medullaris (E, arrow).

にかかわらず，係留解除と修復手術が勧められる99.

\section{Retained medullary cord (Fig. 4C-E)}

二次神経管の尾側部分が終糸へと退縮せず，ヒトや尻 尾のない動物では本来認めない原始脊髄が遺残したもの である，脊髄係留を生じうる，係留解除術を行うが，肉 眼的に異常部分を区別することは困難で, 電気生理学的 に真の脊髄下端と真の最下位神経根を確認し, その尾側

\section{で切断する20).}

著者全員は日本脳神経外科学会への COI 自己申告を完了し ています。本論文の発表に関して開示すべき COI はありませ ん.

\section{文 献}

1) Arai H, Sato K, Okuda O, Miyajima M, Hishii M, Nakanishi 
$\mathrm{H}$, Ishii $\mathrm{H}$ : Surgical experience of 120 patients with lumbosacral lipomas. Acta Neurochir (Wien) 143:857-864, 2001.

2) Blount JP, Elton $\mathrm{S}:$ Spinal lipomas. Neurosurg Focus $\mathbf{1 0}$ : e3, 2001.

3) Cools MJ, Al-Holou WN, Stetler WR Jr, Wilson TJ, Muraszko KM, Ibrahim M, La Marca F, Garton HJ, Maher CO : Filum terminale lipomas : imaging prevalence, natural history, and conus position. J Neurosurg Pediatr 13 : 559-567, 2014.

4) Dias MS, McLone DG : Normal and abnormal early development of the nervous system. in McLone DG (ed) : Pediatric Neurosurgery: Surgery of the Developing Nervous System. Philadelphia, W. B. Saunders, 2001, pp.31-40.

5) Gomi A, Oguma H, Furukawa R : Sacrococcygeal dimple : new classification and relationship with spinal lesions. Childs Nerv Syst 29: 1641-1645, 2013.

6) Harada A, Nishiyama K, Yoshimura J, Sano M, Fujii Y : Intraspinal lesions associated with sacrococcygeal dimples. $J$ Neurosurg Pediatr 14:81-86, 2014.

7) Kulkarni AV, Pierre-Kahn A, Zerah M : Conservative management of asymptomatic spinal lipomas of the conus. Neurosurgery 54:868-875, 2004.

8) La Marca F, Grant JA, Tomita T, McLone DG : Spinal lipomas in children : outcome of 270 procedures. Pediatr Neurosurg 26: 8-16, 1997.

9) Lee JY, Kim SP, Kim SW, Park SH, Choi JW, Phi JH, Kim SK, Pang D, Wang KC: Pathoembryogenesis of terminal myelocystocele : terminal balloon in secondary neurulation of the chick embryo. Childs Nerv Syst $29:$ 1683-1688, 2013.

10) McNeely PD, Howes WJ : Ineffectiveness of dietary folic acid supplementation on the incidence of lipomyelomeningocele: pathogenetic implications. J Neurosurg 100 (2 Supple Pediatrics) : 98-100, 2004.

11）森山徳秀, 樀 俊哉, 岡田文明, 圓尾圭史, 井上真一, 堀之内豊, 吉矢晋一: 阪神地区での脊柱検診の現状と潜 在性二分脊椎の疫学的検討 (第 3 報). 小児の脳神経 36: 542-544, 2011.

12) Morota $\mathrm{N}$, Ihara $\mathrm{S}$, Ogiwara $\mathrm{H}:$ New classification of spinal lipomas based on embryonic stage. J Neurosurg Pediatr 19: 428-439, 2017.

13) O’Neill BR, Gallegos D, Herron A, Palmer C, Stence NV, Hankinson TC, Corbett Wilkinson C, Handler MH : Use of magnetic resonance imaging to detect occult spinal dysraphism in infants. J Neurosurg Pediatr 19:217-226, 2017.

14) Pang D, Dias MS, Ahab-Barmada M : Split cord malformation. Part I : A unified theory of embryogenesis for double spinal cord malformations. Neurosurgery 31:451-480, 1992.

15) Pang D, Zovickian J, Oviedo A, Moes GS : Limited dorsal myeloschisis: a distinctive clinicopathological entity. Neurosurgery $67:$ 1555-1580, 2010.

16) Pang D : Total resection of complex spinal cord lipomas: how, why, and when to operate? Neurol Med Chir (Tokyo) 55: 695-721, 2015.

17) Pierre-Kahn A, Zerah M, Renier D, Cinalli G, Sainte-Rose C, Lellouch-Tubiana A, Brunelle F, Le Merrer M, Giudicelli Y, Pichon J, Kleinknecht B, Nataf F : Congenital lumbosacral lipomas. Childs Nerv Syst $13: 298-334,1997$.

18) Radmanesh F, Nejat F, El Khashab M : Dermal sinus tract of the spine. Childs Nerv Syst $26: 349-357,2010$.

19）坂本博昭：二分脊椎. 山崎麻美, 坂本博昭: 小児脳神経 外科学 改訂 2 版. 京都, 金芳堂, 2015, pp.248-317.

20) Sala F, Barone G, Tramontano V, Gallo P, Ghimenton C : Retained medullary cord confirmed by intraoperative neurophysiological mapping. Childs Nerv Syst 30 : 1287-1291, 2014.

21）重田裕明：潜在性二分脊椎（春髄脂肪腫を除く）：先天性 皮膚洞, 緊張終糸, 神経腸管囊胞, 分離脊髄奇形, 尾部 退行症候群など。No Shinkei Geka 39:513-527, 2011.

22) Talamonti G, D’Aliberti G, Nichelatti M, Debernardi A, Picano M, Redaelli T : Asymptomatic lipomas of the medullary conus : surgical treatment versus conservative management. J Neurosurg Pediatr 14:245-254, 2014.

23) Tamura G, Morota N, Ihara S : Impact of magnetic resonance imaging and urodynamic studies on the management of sacrococcygeal dimples. J Neurosurg Pediatr 20:289-297, 2017.

24) Wykes V, Desai D, Thompson DN : Asymptomatic lumbosacral lipomas - a natural history study. Childs Nerv Syst 28: 1731-1739, 2012.

25）吉藤和久，師田信人，井原 哲：小児における腰仙部脊 柱管後方成分形成の検討. 小児の脳神経 $32: 426-429$, 2007.

\section{潜在性二分脊椎}

吉藤 和久 大森 義範 小柳 泉 師田 信人 三國 信啓

潜在性二分脊椎は, 神経管形成異常による先天奇形のうち皮膚欠損・髄液漏がないものを指し, 閉 鎖性二分资椎ともいう. 発生過程（脊索形成，一次神経管形成，二次神経管形成）で生じる異常の時 期・種類により，種々の疾患が含まれる，脊髄係留，脊髄圧迫，神経組織形成不全が原因で神経障害 を生じうる. 皮膚病変, 鎖肛, 泌尿·生殖器奇形は診断契機として重要である. 神経組織形成不全以 外の脊䚛係留・圧迫に対しては手術が有効な可能性がある. 症候性例に対する手術は広く理解されて いるが，小児では無症候例でも予防手術が必要，あるいは検討される病態が多い. 手術は治療の始点 であり, 長期にわたり複数診療科による包括的サポートが必要である. 